\title{
Distribution and spread of bark beetles (Coleoptera: Scolytidae) around the Gulf of Finland: a comparative study with notes on rare species of Estonia, Finland and North-Western Russia
}

\author{
Kaljo Voolma, Mikhail J. Mandelshtam, Alexander N. Shcherbakov, Eugene B. Yakovlev, \\ Heino Õunap, Ilmar Süda, Boris G. Popovichev, Tatiana V. Sharapa, Tamara V. Galasjeva, \\ Roman R. Khairetdinov, Vladimir A. Lipatkin \& Ekaterina G. Mozolevskaya
}

Voolma, K., Mandelshtam, M. J., Shcherbakov, A. N., Yakovlev, E. B., Õunap, H., Süda, I., Popovichev, B. G., Sharapa, T. V., Galasjeva, T. V., Khairetdinov, R. R., Lipatkin, V. A. \& Mozolevskaya, E. G. 2004: Distribution and spread of bark beetles (Coleoptera: Scolytidae) around the Gulf of Finland: a comparative study with notes on rare species of Estonia, Finland and North-Western Russia. Entomol. Fennica 15: 198-210.

A long-term faunistic study of bark beetles (Coleoptera: Scolytidae), conducted in Estonia, as well as in Karelia, Leningrad (St. Petersburg) and Murmansk provinces of Russia, enables a comparison of the species composition of bark beetles in the regions bordering Finland. Altogether the distribution patterns of 83 species of scolytids are examined. The northern borders of the distribution range for Scolytus scolytus, S. multistriatus, S. laevis, Hylastes ater, H. opacus, Orthotomicus longicollis, Pityogenes trepanatus, Ips amitinus and Cryphalus abietis in Northern Europe are redefined. The list of bark beetles for Estonia and NorthWestern Russia (Karelia, Leningrad and Murmansk provinces) with their occurrence in some biogeographical provinces of Fennoscandia (Ik, Kl, Kon, Ks, Kk, Lim) is given. Recent records of bark beetles, endangered or rare in Finland, and their current distribution in the neighbouring regions are discussed.

K. Voolma, Forest Research Institute, Estonian Agricultural University, Kreutzwaldi 5, 51014 Tartu, Estonia; E-mail: kvoolma@eau.ee

M. Ju. Mandelshtam, Forest Technical Academy, Institutskii alleyway 5, St. Petersburg, 194021 Russia; E-mail:michail@MM13666.spb.edu

A. N. Shcherbakov, Moscow State Forest University, $1^{\text {st }}$ Institute Str. 1, Mytishchi-

5, Moscow region, 141005 Russia; E-mail: anscherb@mail333.com

E. B. Yakovlev, Karelian Institute of Forestry, Pushkin Str. 11, Petrozavodsk, 185610 Russia; E-mail: jevgeni.jakovlev@metla.fi

H. Ounap, Centre of Forest Protection and Silviculture, Rõomu tee 2, 51013 Tartu, Estonia; E-mail: heino.ounap@metsad.ee

I. Süda, Forest Research Institute, Estonian Agricultural University, Kreutzwaldi 5, 51014 Tartu,Estonia; E-mail: isyda@eau.ee

B. G. Popovichev, Forest Technical Academy, Institutskii alleyway 5, St. Petersburg, 194021 Russia; E-mail: forestbg@city.com.ru

T. V. Sharapa, Moscow State Forest University, $1^{\text {st }}$ Institute Str. 1, Mytishchi-5, 
Moscow region, 141005 Russia; E-mail: ecolog@mgul.ac.ru

T. V. Galasjeva, Moscow State Forest University, ${ }^{\text {st }}$ Institute Str. 1, Mytishchi-5, Moscow region, 141005 Russia; E-mail: ecolog@mgul.ac.ru

R. R. Khairetdinov, Moscow State Forest University, $1^{\text {st }}$ Institute Str. 1, Mytishchi5, Moscow region, 141005 Russia; E-mail: ecolog@mgul.ac.ru

V. A. Lipatkin, Moscow State Forest University, $1^{\text {st }}$ Institute Str. 1, Mytishchi-5, Moscow region, 141005 Russia; E-mail: ecolog@mgul.ac.ru

E. G. Mozolevskaya, Moscow State Forest University, $1^{\text {st }}$ Institute Str. 1, Mytishchi-5, Moscow region, 141005 Russia; E-mail: moz-ekaterina@yandex. $r u$

Received 19 February 2002, accepted 4 August 2004

\section{Introduction}

Natural barriers, such as seas (e.g. the Gulf of Finland between Estonia and Finland) represent barriers for the spread of insects. Although bark beetles (Coleoptera: Scolytidae) can be dispersed over quite a long distance by wind (Nilssen 1984, Byers 2000), the main way for their spreading seems to be step by step through their natural habitats. The route via Estonia and Leningrad (St. Petersburg) Province of Russia, i.e. the way bypassing Gulf of Finland, was considered the most probable route for the recent invasion of Ips amitinus Eichh. into Finland (Mandelshtam 1999). On the other hand, Scolytus laevis Chap., inhabiting elm trees (Ulmus spp.), was recorded in Estonia already in the 1930s (Kristian 1937, Leius 1939), i.e. it has been present in the vicinity of Finland for at least 70 years. S. laevis occurs even on the northern coastal region close to the Gulf of Finland (Voolma et al. 2000), but it is still absent in Finland (Heliövaara et al. 1998) despite of its host trees Ulmus glabra and U. laevis growing in central and Southern Finland (Hämet-Ahti et al. 1992, Mattila \& Vakkari 1997). In the Leningrad Province of Russia, the range of S. laevis is limited to the southern parts of the province (Mandelshtam \& Popovichev 2000). Thus, S. laevis cannot enter Finland via Isthmus Karelicus, and it has failed to spread over the Gulf of Finland for at least 70 years. A possible land route for the expansion of southern species northward to Finland runs through the north-western region of Russia, the Leningrad Province and Karelia.

The North-Eastern part of Europe, including Eastern Fennoscandia, Northern Baltics and
North-Western Russia, is covered with boreal coniferous and mixed forests where the dominating conifer species are Scots pine (Pinus sylvestris) and Norway spruce (Picea abies), and the deciduous trees include birches (Betula pendula, $B$. pubescens) and aspen (Populus tremula), with a small proportion of other broad-leaved species, such as Tilia cordata, Quercus robur, and Ulmus spp. As host trees, these species are an indispensable prerequisite for the distribution of bark beetles. Because of the relatively short distances among Southern Finland, Estonia and NorthWestern Russia, there is no substantial difference in the species composition of woody plants in the regions. However, the forests in Finland, Russia and Estonia have been subjected to different human impact during the last century (Siitonen et al. 1995). Estonian and Russian forests are considered more "natural" i.e. less intensively managed than the Finnish forests. They can serve as refugia for insect species negatively affected by forest management, as demonstrated by comparative studies of some insects groups of Finnish and Russian Karelia (Siitonen \& Martikainen 1994, Siitonen et al. 1995, 1996, Rutanen \& Kashevarov 1997). Differences in forestry history and intensity of forest management between Finland and Russia have consequently a considerable impact on the bark beetle fauna (Martikainen et al. 1996).

The faunistics of bark beetles has been thoroughly investigated in Finland for a long time. Overviews of the Finnish bark beetles (Saalas 1917, 1923, 1931) have been of great importance not only for Finland but also for Karelia. Checklists of Scolytidae for separate provinces of Fin- 
land were scrutinized by several authors (e.g. Nuorteva 1963, 1971). Later, the fauna of scolytids in the Nordic countries, including Finland, was reviewed and the distribution maps were compiled by Lekander et al. (1977). The quantitative biogeography of bark beetles in Northern Europe was analyzed by Heliövaara et al. (1991). Current knowledge on bark beetles of Finland was summarized by Heliövaara et al. (1998). However, in these works neither Karelia (currently included in the biogeographical region of Fennoscandia) nor the neighbouring Baltic countries were discussed.

During the recent decades, the bark beetle fauna of Estonia (Voolma et al. 1996, 1997a, 1998, 2000), Karelia (Yakovlev et al. 1986, 2000, Sharapa \& Shcherbakov 2000), the Murmansk (Mozolevskaya et al. 1981, Sharapa 1985, Mozolevskaya \& Sharapa 1996) and Leningrad provinces (Mandelshtam \& Popovichev 2000) has been revised. Each of these papers added new species to the regional faunas, previously unknown from these territories. Besides, the documented expansion of the range of Ips amitinus Eichh. (Koponen 1975, 1980, Mandelshtam 1999), previously regarded as a southern species, has recently reached more northern regions. Therefore, a comparative faunistic analysis of Scolytidae in the countries adjacent to Finland may provide new clues on the finding of new species in Finland in the future. In addition, checklists of bark beetles of the former Finnish territories, Isthmus Karelicus (biogeographical province Ik and a part of province Kl), the Karelian biogeographical provinces Kon (Kivach Nature Reserve with nearby areas), Ks (National Park of Paanajärvi) and Kk (Keret Archipelago and Kandalaksha Nature Reserve), and the Murmansk region (Lappland Nature Reserve, Lim) have been taken into account.

\section{Material and methods}

The paper is based on long-term investigations conducted by the authors in different localities of North-Western Russia (Karelia, Leningrad and Murmansk provinces) and in the Republic of Estonia. Biogeographical provinces of Fennoscandia concerning the study, and main collection

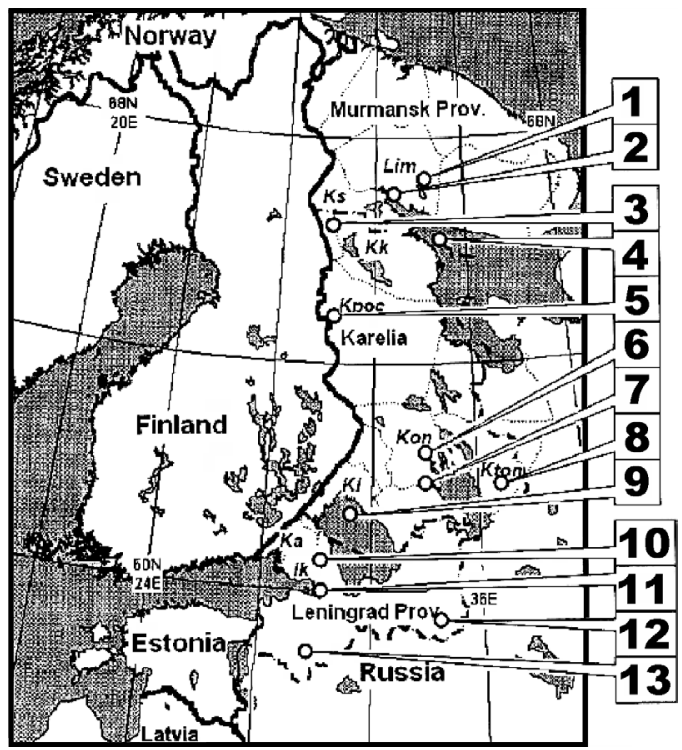

Fig. 1. The study region (Estonia and North-Western Russia) with the biogeographical provinces of eastern Fennoscandia (Ik, Ka, Kl, Kon, Kton, Kpoc, Ks, Kk, Lim). Main collection sites in Russia are indicated with numbers. Murmansk Province: 1 - Khibiny Mountains, environs of Monchegorsk (Lim); 2 - Isle Velikii, Kandalaksha Nature Reserve (Kk); Karelia: 3 - Paanajärvi National Park (Ks and Kk); 4 - Isle Srednii (Kk); 5 - Kalevala National Park (Kpoc); 6 - Kivach Nature Reserve (Kon); 7 - Petrozavodsk area (Kon); 8 - Pudozh (Kton); 9 - Valamo archipelago (KI); Leningrad (St. Petersburg) Prov:: 10 - Lembolovo (lk) and Vaskelovo; 11 St. Petersburg; 12 - Cherentsovo, Tikhvin Distr.; 13 Jashchera, Luga Distr.

sites, in Russia are shown in Fig. 1. The complete set of collection sites cannot be mapped in detail due to the small resolution of the map. Some additional collecting sites are listed in the text; all sites can be found from sources listed in References [e.g. Mandelshtam \& Popovichev (2000) for Leningrad Province etc.].

The fauna of the Leningrad (St. Petersburg) province was reconstructed using the analysis of bark beetles collected from 60 localities of the province between 1987 and 2001 (Mandelshtam \& Popovichev 2000), with more than 20,000 specimens being collected. The fauna of the Fennoscandian biogeographical province Ik (Isthmus Karelicus) was compiled by combining data of several years, collected in the St. Petersburg area, Zelenogorsk (Terijoki), the River Sestra (Solnechnoye), Roschino (Raivola), Petja- 
järvi, Sosnovo (Rautu), Orekhovo and Lembolovo, and in the vicinity of Vaskelovo, an area separated from Lembolovo (Ik) by a river.

The fauna of Southern Karelia (the Fennoscandian province $\mathrm{Kl}$ ) was compiled on the basis of local faunal lists for Valamo, Loimola, Kuznechnoye and Vladimirskaya Buchta. The fauna of Valamo was studied during three visits to Valamo Island (August 1989, June 1990 and 1992) by the expedition of the St. Petersburg State University. The list of the bark beetles of the Kivach Nature Reserve (Kon) was completed during the expeditions of the Moscow State Forestry University (MSFU) in 1987 and in 1989 (Mosolevskaja et al. 1991). About 7,000 specimens of bark beetles in Kivach Nature Reserve were trapped. The fauna of the Paanajärvi National Park (Ks and Kk) was the subject of study in the course of joint expeditions of the Karelian Forest Institute and the MSFU in 1998-2000 (Yakovlev et al. 2000). Data on the bark beetles of Karelia in general were collected during over 15 years (Yakovlev et al. 1986). About 3,000 specimens of bark beetles were collected in Paanajärvi National Park and about 2,000 in other regions of Karelia.

The fauna of the Murmansk Province (the Fennoscandian biogeographical provinces $\mathrm{Kk}$ and Lim) was studied during expeditions of the MSFU in 1972-1994 (Mozolevskaja \& Sharapa 1996). More than 50,000 specimens were collected in the Murmansk Province during these field studies. Because Hylastes spp. were overrepresented in window traps in Karelia, the total figures do not reflect the exact species prevalence and the efforts to compile the bark beetle fauna. More importantly, a specialized search for bark beetles was performed in all regions.

The list and distribution maps of the bark beetles of Estonia were completed on the basis of more than 16,000 collection specimens and by collecting insects from nearly all squares of 10x10 km of the country (Voolma et al. 2000, Fig. 2).

The collections of the authors' institutions, and those of the Zoological Institute of Russian Academy of Sciences, St. Petersburg (ZISP) and the Moscow Zoological Museum (MZM) were examined for obtaining additional information about species distribution in the region. Old refer-

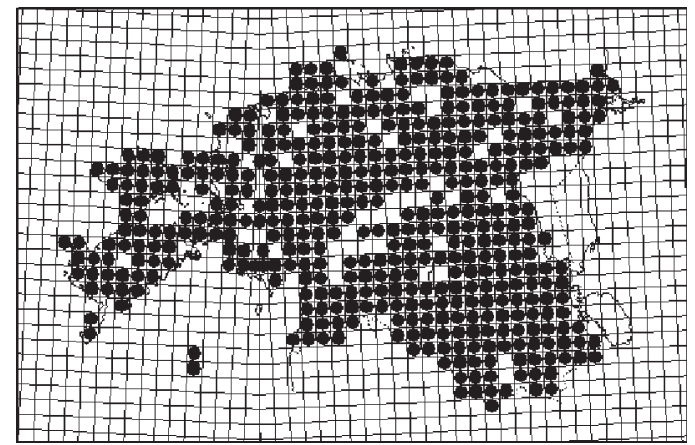

Fig. 2. Locality records of Scolytidae according to the UTM squares of $10 \times 10 \mathrm{~km}$ in Estonia.

ences on the occurrence of bark beetles in the region were re-evaluated. The nomenclature of bark beetles used in this paper follows Silfverberg (1992), with some additions by Pfeffer (1994) and Bright \& Skidmore (2002).

\section{Results}

Data on the distribution of bark beetles in Estonia (Voolma et al. 2000), in the Leningrad Province of Russia (Mandelshtam \& Popovichev 2000), in Southern Karelia (Yakovlev et al. 1986, Mosolevskaja et al. 1991), in Northern Karelia (Mozolevskaja \& Sharapa 1996, Yakovlev, 1996, Yakovlev et al. 2000), and in the Murmansk Province (Mozolevskaja \& Sharapa 1996) were re-checked and supplemented with new records by the authors. Altogether 83 species of bark beetles were recorded from Estonia, Finland and North-Western Russia including Karelia, the Murmansk and Leningrad provinces. Table 1 presents a list of bark beetles known from Finland, Estonia and North-Western Russia with their occurrence according to biogeographical provinces of Eastern Fennoscandia.

The following 30 species occurred in all studied regions: Hylurgops glabratus, H. palliatus, Hylastes brunneus, H. cunicularius, Xylechinus pilosus, Tomicus minor, T. piniperda, Dendroctonus micans, Phloeotribus spinulosus, Polygraphus poligraphus, P. subopacus, P. punctifrons, Scolytus ratzeburgi, Pityogenes bidentatus, P. chalcographus, P. quadridens, Orthotomicus laricis, O. proximus, Ips acuminatus, I. sexdentatus, I. typographus, Dryocoetes 
Table 1. Bark beetles (Coleoptera, Scolytidae) known from Finland, Estonia and North-Western Russia [Leningrad (St. Petersburg) Province, Karelia and Murmansk Province], with their occurrence in some biogeographical provinces of Fennoscandia. Abbreviations: Fin = Finland, Est $=$ Estonia, St. Ptb - Leningrad (St. Petersburg) province, Ik, Kl, Kon, Ks, Kk, Lim - biogeographical provinces of Fennoscandia in Russian Karelia, and Mur = Murmansk province of Russia. $(+)=$ records that were not verified with labelled collection specimens and thus not checked by the authors; $(1)$ = unique records; $/+$ / = records near province borders, and $\mathrm{i}=$ introduced with imported timber.

\begin{tabular}{|c|c|c|c|c|c|c|c|c|c|}
\hline \multirow[t]{2}{*}{ Species } & \multirow[t]{2}{*}{ Fin } & \multirow[t]{2}{*}{ Est } & \multicolumn{2}{|c|}{ St. Ptb } & \multicolumn{4}{|c|}{ Russian Karelia } & \multirow{2}{*}{$\frac{\text { Mur }}{\text { Lim }}$} \\
\hline & & & & Ik & $\mathrm{KI}$ & Kon & Ks & $\mathrm{Kk}$ & \\
\hline Hylurgops glabratus (Zett.) & + & + & + & + & + & + & + & + & + \\
\hline H. palliatus (Gyll.) & + & + & + & + & + & + & + & + & + \\
\hline Hylastes brunneus Er. & + & + & + & + & + & + & + & + & + \\
\hline H. cunicularius Er. & + & + & + & + & + & + & + & + & + \\
\hline H. angustatus (Hbst.) & - & $(+)$ & - & - & - & - & - & - & - \\
\hline H. attenuatus Er. & - & (1) & - & - & - & - & - & - & - \\
\hline H. opacus Er. & + & + & + & + & - & + & - & + & + \\
\hline H. plumbeus Blandf. & - & - & + & + & - & - & - & - & - \\
\hline Hylesinus crenatus (F.) & + & + & + & - & - & - & - & - & - \\
\hline H. fraxini (Panz.) & + & + & + & - & - & - & - & - & - \\
\hline H. varius $(\mathrm{F})$. & (1) & + & - & - & - & - & - & - & - \\
\hline Xylechinus pilosus (Ratz.) & + & + & + & + & + & + & + & + & + \\
\hline Hylurgus ligniperda (F.) & - & + & + & - & - & - & - & - & (1) \\
\hline Tomicus minor (Htg.) & + & + & + & + & + & + & + & + & + \\
\hline T. piniperda (L.) & + & + & + & + & + & + & + & + & + \\
\hline Dendroctonus micans (Kug.) & + & + & + & + & + & + & + & + & + \\
\hline Phloeotribus spinulosus (Rey) & + & + & + & + & + & + & + & + & + \\
\hline Polygraphus subopacus (Thoms.) & + & + & + & + & + & + & + & + & + \\
\hline P. poligraphus (L.) & + & + & + & + & + & + & + & + & + \\
\hline P. punctifrons Thoms. & + & + & + & + & + & + & + & + & + \\
\hline Carphoborus cholodkovskyi Spess. & + & + & + & - & - & + & - & + & + \\
\hline C. rossicus Sem. & + & - & + & - & - & + & - & + & + \\
\hline C. minimus ( $\mathrm{F}$.) & (1) & - & (1) & - & - & - & - & - & - \\
\hline C. teplouchovi Spess. & - & - & - & - & - & - & - & + & + \\
\hline Scolytus multistriatus (Marsh.) & - & + & + & - & - & - & - & - & - \\
\hline S. scolytus (F.) & - & + & + & - & - & - & - & - & - \\
\hline S. triarmatus (Egg.) & - & + & - & - & - & - & - & - & - \\
\hline S. ratzeburgi Jans. & + & + & + & + & + & + & + & + & + \\
\hline S. laevis Chap. & - & + & + & - & - & - & - & - & - \\
\hline S. mali (Bechst.) & + & + & + & - & - & - & - & - & - \\
\hline S. intricatus (Ratz.) & + & + & + & + & - & - & - & - & - \\
\hline S. carpini (Ratz.) & - & $(+)$ & - & - & - & - & - & - & - \\
\hline S. morawitzi Sem. & - & - & - & - & - & _- & - & - & + \\
\hline S. rugulosus (Ratz.) & + & + & + & - & + & - & - & - & - \\
\hline Pityogenes chalcographus (L.) & + & + & + & + & + & + & + & + & + \\
\hline P. irkutensis Egg. & + & - & + & - & - & + & $1+1$ & + & + \\
\hline$P$. saalasi Egg. & + & - & $(+)$ & - & - & - & + & + & + \\
\hline P. trepanatus (Nördl.) & + & + & + & + & - & - & - & - & - \\
\hline P. quadridens (Htg.) & + & + & + & + & + & + & + & + & + \\
\hline P. bidentatus (Hbst.) & + & + & + & + & + & + & + & + & + \\
\hline Orthotomicus longicollis (Gyll.) & + & + & + & - & - & + & - & - & - \\
\hline O. starki Spess. & - & _- & + & _- & - & - & - & + & + \\
\hline O. proximus (Eichh.) & + & + & + & + & + & + & + & + & + \\
\hline O. suturalis (Gyll.) & + & + & + & + & - & + & + & + & + \\
\hline O. laricis (F.) & + & + & + & + & + & + & + & + & + \\
\hline Ips acuminatus (Gyll.) & + & + & + & + & + & + & + & + & + \\
\hline l. sexdentatus (Börn.) & + & + & + & + & + & + & + & + & + \\
\hline
\end{tabular}


I. duplicatus (Sahlb.)

I. typographus (L.)

I. amitinus (Eichh.)

I. cembrae (Heer)

I. subelongatus Motsch.

Lymantor coryli (Perris)

Dryocoetes baikalicus Reitt.

D. alni (Georg)

$D$. autographus (Ratz.)

$D$. hectographus Reitt.

Crypturgus subcribrosus Egg.

C. cinereus (Hbst.)

C. pusillus (Gyll.)

C. hispidulus Thoms.

Trypodendron domesticum (L.)

Tr. laeve Egg.

Tr. lineatum (Oliv.)

Tr. signatum (F.)

Xyleborus dispar (F.)

$X$. cryptographus (Ratz.)

$X$. monographus (F.)

Trypophloeus alni (Lind.)

T. bispinulus Egg.

T. asperatus (Gyll.)

T. discedens Palm

Ernoporicus caucasicus (Lind.)

Ernoporus tiliae (Panz.)

Cryphalus abietis (Ratz.)

C. saltuarius Weise

Pityophthorus micrographus (L.)

P. lichtensteinii (Ratz.)

P. morosovi Spess.

P. glabratus Eichh.

P. traegardhi Spess.

$P$. lapponicus Stark

Gnathotrichus materiarius (Fitch)

$\begin{array}{ccccccccc}+ & + & + & + & + & + & - & + & + \\ + & + & + & + & + & + & + & + & + \\ + & + & + & + & + & + & + & + & - \\ - & - & + & - & - & - & - & - & + \\ \text { i } & \text { i } & - & - & - & - & - & - & - \\ + & + & + & - & - & - & - & - & + \\ - & - & - & - & - & - & - & - & + \\ + & + & + & + & + & + & ++ & + & + \\ + & + & + & + & + & + & + & + & + \\ + & + & + & + & + & + & + & + & + \\ + & + & & & & & & & \\ + & + & + & + & + & + & + & + & + \\ + & + & + & + & + & + & + & + & + \\ + & + & + & + & + & + & + & + & + \\ + & + & + & ++1 & + & - & - & - & - \\ + & + & + & + & + & + & + & + & - \\ + & + & + & + & + & + & + & + & + \\ + & + & + & + & + & + & + & + & + \\ + & + & + & ++1 & + & - & - & - & + \\ + & + & + & ++ & + & + & - & - & + \\ - & (+) & (+) & - & - & - & - & - & - \\ + & + & + & + & - & - & - & - & + \\ + & + & + & - & + & - & ++ & + & - \\ + & + & + & - & + & - & - & + & + \\ + & + & - & - & - & - & - & - & - \\ (1) & - & - & - & - & - & - & - & - \\ + & + & + & - & - & - & - & - & - \\ + & + & + & + & - & - & - & - & - \\ + & + & + & + & + & + & + & + & + \\ + & + & + & + & + & + & + & + & + \\ + & + & + & + & + & + & +1 & + & + \\ + & + & + & - & - & - & - & + & + \\ + & ++ & (1) & - & - & ++ & - & - & - \\ + & + & + & - & - & + & + & - & + \\ + & - & - & - & - & - & - & - & (+) \\ \text { i } & - & - & - & - & - & - & - & - \\ + & + & & & & & & & + \\ + & + & + & & & & & & + \\ + & +\end{array}$

Hylesinus varius was found only in Southern Finland and Estonia, whereas Scolytus mali was recorded in Southern Finland, Estonia and in the Leningrad Province. The following five species were recorded only from Estonia and from the Leningrad Province (excluding Ik and K1): Hylurgus ligniperda, Scolytus scolytus, S. laevis, S. multistriatus.

The records of $X$. monographus and Hylastes angustatus from Estonia, and the records of X. monographus and Hylurgus ligniperda from the Leningrad Province, were derived from references only and could not be checked by verifying with the available collection specimens.

Hylastes ater, Hylesinus oleiperda and Xyleborinus saxesenii, which all have been reported in some earlier references, do probably not have viable, permanent populations in the region. 


\section{Discussion}

Several papers published since Saalas (1917, $1923,1931)$ have added some new information to the Finnish and its separate provinces' scolytid fauna (e.g. Nuorteva 1955, 1963, 1971, Koponen 1975, 1980, Muona \& Viramo 1986, Muona 1990, 1994, Sippola et al. 1995, Viramo 1996, Rutanen \& Kashevarov 1997, Martikainen et al. 1999, Martikainen 2000, 2001). At the same time, the previous lists of the bark beetles of Estonia (Zolk 1932, Rubel 1964) were revised and supplemented by Voolma et al. (1996, 1997b, 1998, 2000). The list of bark beetles of the Leningrad Province (Gornostaev 1917) was significantly extended by Mandelshtam \& Popovichev (2000). Papers on Southern Karelia, published since Titova (1959), have given much new information on the fauna of this region (Yakovlev et al. 1986, Mozolevskaja et al. 1991). Although the North Karelian fauna of Scolytidae has so far been poorly studied, it has recently caught the attention of researchers (Yakovlev et al. 2000). By now, the bark beetles of this region are relatively well known. The insect fauna of the Murmansk province, first investigated by V. N. Stark (Nestertschuk 1930, Stark 1930), was reviewed by Mozolevskaya \& Sharapa (1996). All the mentioned papers have added new species to the regional faunas, and a comparative analysis of the present distribution of scolytids is required.

An example of a useful comparative approach in the case of neighbouring countries is the monitoring of continuously expanded range of Ips amitinus. First recorded by Mikutowicz (1905) in Estonia, and studied further in detail in Finland (Nuorteva 1955, Koponen 1975, 1980), it was later detected in North-Western Russia (Mandelshtam 1999). The revision of the authors' collections has allowed to report new findings of the species in the easternmost parts of the Leningrad Province (Mandelshtam \& Popovichev 2000), in the Kivach Nature Reserve (Kon), in Northern Karelia (Paanajärvi National Park, Ks and Kk, Päozero areas, and Sredny Island and adjacent mainland territories, Kk, Loukhi region of Karelia). I. amitinus was also reported by Muona and Viramo (1986) in the province Ks in Finland. However, in the collections of T. V. Sharapa, a specimen originated on pine from the Murmansk province, Kk (Kandalaksha Nature Reserve, 27 July 1989). The last finding gave a new evidence of the ongoing expansion of the range of $I$. amitinus. Now the species occurs even beyond the Polar Circle. In 2000, E. Yakovlev reported a new finding of I. amitinus from the Pudozh region (Kton), indicating that the distribution range of I. amitinus has expanded not only northward, but also eastward. Interestingly enough, the enlargement of the range of I. amitinus does not occur in the south-eastern directions and the species is still absent in the Moscow province (Nikitsky et al. 1996, 1998, Petrov \& Nikitskii 2001).

For I. amitinus, the most likely route of the contemporary colonization of Finland was established through Estonia and the Leningrad Province, bypassing the Gulf of Finland (Mandelshtam 1999). However, Lekander et al. (1977) suggested a different contemporary route of colonization in Finland for Cryphalus abietis Ratz.. Lekander et al. (1977) have referred that C. abietis, recorded only in the South-Western Finland, was introduced to Finland after an artificial regeneration of spruce stands in Denmark via Sweden, the Åland Archipelago and the Gulf of Bothnia. The distribution data on the occurrence of C. abietis throughout Estonia, and in the marine parts of the Leningrad province, that was not taken into account by Lekander et al. (1977), might support the existence of another route. Indeed, both C. abietis and C. saltuarius Weise can be found in the southern part of the former territory of Finland (Mesterjärvi, Ik), and even in Viipuri (Vyborg, Ka). C. abietis is quite common already in the Southern Isthmus Karelicus (Morskaya railway station, near St. Petersburg). Nevertheless, in the area of Virolahti (Ka), only C. saltuarius has been encountered (Nuorteva 1963), but the presence of C. abietis in Viipuri (park "Mon Repos") suggests that both $C$. abietis and $C$. saltuarius occur in the province Ka. Thus, it appears that the "southern" species $C$. abietis, restricted to the warmest coastal regions of $\mathrm{Ik}, \mathrm{Ka}$ and Southern Finland, could enter Finland simply from the neighbouring territories of Russia, and therefore the proposed route through the Gulf of Bothnia seems unnecessarily complicated. We suggest that the route of $C$. abietis to Finland was probably the same as that of the Norway spruce (Moe 1970) and spruce-inhabiting I. amitinus, 
i.e. bypassing the Gulf of Finland. However, C. abietis appeared in Finland much earlier, probably during one of the warm periods of post-glaciation era. The current range of $C$. abietis in the region is probably restricted to South-Western Finland, whole Estonia, the Southern Isthmus Karelicus and the south-western parts of the Leningrad Province. No documented evidence was found on the breeding of $C$. abietis in the Murmansk Province or Northern Karelia (Mozolevskaya \& Sharapa 1996, Muona \& Viramo 1986, Yakovlev 1996, Yakovlev et al. 2000), and only C. saltuarius from the Murmansk Province was found in the collections of Stark and V. A. Lipatkin, and from Northern Karelia ( $\mathrm{Ks}$ and $\mathrm{Kk}$ ) in the authors' collections.

The revision of Estonian (Voolma et al. 1996, 1997a) and Russian insect collections (Mandelshtam \& Popovichev 2000, Yakovlev et al. 2000) has allowed to exclude Hylastes ater $\mathrm{Pk}$. from the regional faunal lists for Estonia, the Leningrad province and Karelia. Seemingly, permanent populations in Finland do not occur either (Heliövaara et al. 1998). In Northern Europe, $H$. brunneus Er. (=H. aterrimus Egg.) completely substitutes for $H$. ater. The northern border of the distribution of $H$. ater in the Baltic countries and Russia is not clear. No documented evidence, based on collection specimens, is available on the breeding of $H$. ater in the Murmansk Province. However, numerous specimens of $H$. brunneus from the Kola Peninsula and Northern Karelia are preserved in the collections of V. N. Stark (ZISP), T. V. Sharapa, V. A. Lipatkin and A. N. Shcherbakov (MSFU), as well as M. J. Mandelshtam. The northernmost border of the distribution of $H$. ater in the Baltic countries crosses Latvia (Telnov et al. 1997) and the Moscow Province in Russia (Nikitsky et al. 1996, Petrov \& Nikitskii 2001). Thanks to the courtesy of N. B. Nikitsky (MZM), we could study the extensive collections from the Moscow Province, collected using window traps. Unfortunately, we did not find $H$. ater; only one specimen of this species was found in the B. Sokanovsky`s collection (MZM) from the Moscow Province.

In contrast to $H$. ater and Hylastes angustatus Herbst, which should both be removed from the previous lists of bark beetles for North-Western Russia (Yakovlev et al. 1986, Mozolevskaya \&
Sharapa 1996, Mandelshtam \& Popovichev 2000), Hylastes opacus Er. really breeds much further north in Karelia than reported by Lekander et al. (1977). H. opacus, previously reported from south of the $65^{\text {th }}$ parallel (Lekander et al. 1977), was found in the provinces $\mathrm{Kk}$ and Lim, north of the Polar Circle.

Several other examples of "southern" bark beetles breeding in Karelia were verified. Orthotomicus longicollis Gyll., recorded from St. Petersburg (Stark 1952, Mandelshtam \& Popovichev 2000) has successfully bred in pine stands of the Kivach Nature Reserve, Kon, for many years (Mozolevskaja et al. 1991). O. longicollis was first found in Karelia by researchers from MSFU (Mozolevskaja et al. 1991) and was later reported from Karelia (Siitonen et al. 1996).

Of special interest is the finding of Lymantor coryli Perr. on Sorbus aucuparia on the Kola Peninsula (Nestertschuk 1930, Mozolevskaya \& Sharapa 1996). This rare species has not yet been found in Karelia, but it breeds in Prunus padus in the Leningrad Province (Mandelshtam \& Popovichev 2000) and in Frangula alnus in Estonia (Voolma et al. 1997b, Süda 2001).

Xyleborus dispar F., known to breed in Fennoscandia mainly in the areas with high summer temperature (mean temperature in July $+16^{\circ} \mathrm{C}$ or more) (Lekander et al. 1977), was reported far north from the Kola Peninsula (Stark 1930, 1952, Mozolevskaya \& Sharapa 1996).

Pityogenes trepanatus Noerdl., whose distribution in Finland is restricted to the south-western regions (Lekander et al. 1977) and has only occasionally been found in Northern Finland (Lekander et al. 1977) and Sweden (Lundberg 1995), was recently discovered in the Leningrad Province (Lebyazhye, southern coast of the Gulf of Finland) and in Petjajärvi (Ik) (Mandelshtam $\&$ Popovichev 2000). Interestingly, one of the findings of $P$. trepanatus in the Leningrad Province (Lebyazhye) and almost all records in Estonia (Voolma et al. 2000) are restricted to the coast.

None of the Scolytus species breeding on Ulmaceae were found in Finland or Karelia, despite Ulmus trees occurring in Finland and in the Kon province of Karelia (e.g. in Kizhi). The northernmost records of $S$. scolytus F. in Europe have been St. Petersburg city parks, the railway station of Sablino (south of St. Petersburg; Tosno 
district, Leningrad Province), and the Island of Abruka in Estonia (Voolma et al. 1998, Voolma, Süda 1999). It should be mentioned that in Sweden $S$. scolytus has been completely replaced by the related species $S$. triarmatus (Egg.), which was reported from Sweden even farther north, compared with S. scolytus in Estonia (Lundberg 1995). Recently, S. triarmatus has been collected from an elm tree in Southern Estonia (leg./det. I. Süda). The northernmost European finding of $S$. multistriatus Marsh. has been recorded from a park in St. Petersburg (Mandelshtam \& Popovichev 2000). S. laevis Chap. was also found in Northern Estonia (Voolma et al. 2000) and in the central parts of the Leningrad Province (Zhikharevo, River Lava canyon, southern shore of Lake Ladoga) (Mandelshtam \& Popovichev 2000). However, S. laevis has been found much farther north in Sweden and Norway (Lekander et al. 1977). Until now, findings of Scolytus species, at least those of $S$. laevis, can be expected from Finland in areas where Ulmus glabra and U. laevis still grow.

Of special interest are the findings of the "northern" species of Scolytidae. Ips sexdentatus Börner was earlier common throughout Sweden and Finland, but there have been only a few findings in Southern Finland in the 1970s, probably attributed to an accidental introduction (Löyttyniemi 1975, Lekander et al. 1977). In recent decades, I. sexdentatus has also become rare in Sweden and is now included in the national Red List (Gärdenfors 2000). However, several recent findings of $I$. sexdentatus on the former Finnish territory (Leningrad Province) were reported during the last two decades from the vicinity of Lake Vysokinskoe (Ka) and Zelenogorsk (Terijoki, Ik). Although the species can be found throughout the province, it is not frequent there. In mature pine stands of Zelenogorsk, suitable for the breeding of $I$. sexdentatus, the species was recorded only once during the 16 years of monitoring. In Estonia, I. sexdentatus occurs throughout the country but is not numerous, and the records have become more scarce during recent years. I. sexdentatus occurs uniformly but infrequently in Karelia. However, I. sexdentatus cannot be considered a truly "northern" species, because it is distributed also in central and Southern Europe (Konca 1995, Rener \& Maja 2001). Also, mass outbreaks of $I$. sexdentatus have occurred in Turkey (Schönherr et al. 1983) and it has infested pine trees even in Thailand (Browne 1972).

I. acuminatus was relatively common in St. Petersburg and in adjacent areas in the beginning of 1900's (Gornostaev 1917), but occurs now only sporadically there. The decline of $I$. sexdentatus and I. acuminatus Gyll. populations in the region cannot be solely explained by logging the big old-growth pines, but it may also be due to other reasons. The disappearance of I. sexdentatus from Southern Finland is discussed in relation to temperature and competition with Tomicus piniperda (L.) (Löyttyniemi 1975). The latter aspect has also been highlighted by Mandelshtam and Selikhovkin (2003) concerning I. sexdentatus in the Leningrad and Pskov regions of Russia.

Pityogenes saalasi Egg., described from the Kuusamo district (Ks), is still rather common in this region (Paanajärvi) and in the Monchegorsk district (Murmansk Province, Lim), but it has not been encountered in the Leningrad Province after Stark (1952). Pityophthorus traegardhi Spess., another "northern" species, was collected by the authors not only in the Murmansk Province, but also in the Kivach Nature Reserve (Kon) in Karelia and in the Leningrad Province, south of St. Petersburg.

Trypophloeus alni Lind., a rare species in Finland, has been found in the southern parts of province Ik (River Sestra) (Mandelshtam \& Popovichev 1999) and on the Kola Peninsula, Murmansk Province (Stark 1930). Trypophloeus bispinulus Egg. was recently reported for the first time in Karelia (Kk, Paanajärvi, Päozero environs, Loukhi region, 8 August 1998; collected by A. N. Shcherbakov) (Yakovlev et al. 2000).

Pityophthorus lapponicus Stark,1952 was considered having a disjunctive distribution range. The species was reported from the Chibiny Mountains in North-Western Russia, and from the Primorsk Territory, Far-Eastern Russia (Stark 1952). Stark (1930) was the first to mention a new Pityopthorus species from Chibiny, Lapland, and presented it later with a description of a new species, P. lapponicus (Stark 1952). Kurenzov (1941) has described P. lapponicus from the Far East, referring to the Stark's manuscript of "The Fauna of the USSR". Because we have failed to 
find Stark's syntypes, supposedly preserved in ZISP, we had no possibility to confirm the identity of the specimens from Lapland and Primorsk. These may well represent different species, as all specimens from MSFU, determined as P. lapponicus, actually belong to $P$. traegardhi, and there have been no other recent findings of the species on the Kola Peninsula.

The distribution of Trypodendron laeve Egg. (= Tr. piceum Strand, nec Tr. proximum Niij.) in the northern regions was unclear for a long time, owing to the fact that it was confused with $T r$. lineatum Ol. Recent reports by Muona (1990, 1994) support the suggested occurrence of the species including Northern Finland (Ks), Southern Finland and Russia (K1, Ik, Kon), supplemented by the new findings from the Keret Archipelago (Kk), Leningrad Province (Ik and the territories around the Isthmus Karelicus) and Estonia (Voolma 1996, Voolma et al. 2000). Thus, Tr. laeve may be distributed throughout the whole studied region. The cotypes of Tr. laeve from the Natural History Museum, Vienna, Austria, have been studied and found to be distinct from $T r$. proximum Niij. (Mandelshtam \& Popovichev 2000). The types of Tr. laeve originate from Japan, suggesting a Transpalaearctic distribution. The male genitalia, useful for determination of Trypodendron species, have been found identical in the type specimens from Japan and in specimens from Northern Karelia.

Among the species rare in Finland (Kotiranta et al. 1998), several were found in Estonia and North-Western Russia. Xyleborus cryptographus Ratz. is common in Estonia and in the Leningrad Province where it is even abundant in some places, e.g. Kuznechnoye, K1. X. cryptographus has repeatedly been reported from the Murmansk province (Stark 1930, 1952, Mozolevskaya \& Sharapa 1996). Due to the wide distribution and frequent occurrence, this species cannot be referred to as requiring protection in Russia. Carphoborus minimus F. is considered critically endangered (and, in fact, extinct in Finland) and it has not been found in the St. Petersburg areas either (Mandelshtam \& Popovichev 2000). However, one old specimen from St. Petersburg is preserved in B. Sokanovsky's collection (MZM).

Crypturgus subcribrosus Eggers has been treated as a variety and a synonymy of $C$. cinereus
(Herbst) in Russia (Mandelshtam \& Popovichev 2000) and also in Central Europe (Postner 1974, Pfeffer 1994). However, according to Stark (1952), Lekander et al. (1977), Silfverberg (1992) and Lundberg (1995), they belong to a clearly distinguishable, separate species (Õunap 1996, Heliövaara et al. 1998).

Ips cembrae (Heer) and I. subelongatus Motschulsky infest various species of Larix in Europe and Asia. These putative species are distinguished by their host tree and geographic distribution, as it is not possible to distinguish them on the basis of morphological differences (Stauffer et al. 2001). According to many authors (e.g. Postner 1974, Pfeffer 1994), I. subelongatus is treated as a synonym of I. cembrae. However, recent DNA studies suggest that the I. cembraecomplex contains at least two taxa: I. cembrae infesting larch in Europe, and I. subelongatus infesting larch in Asia (Stauffer et al. 2001). In the region of the present study, the larch bark beetles (Ips cembrae or I. subelongatus) were not found in Larix, but they were instead recorded from spruce in St. Petersburg (Mandelshtam \& Popovichev 2000) and from pine in the Murmansk Province (Nestertschuk 1930, Stark 1930, Mozolevskaya \& Sharapa 1996). I. subelongatus has been imported to Finland on roundwood from Siberia (Siitonen 1990, 2000). The species has also been found in timber imported to Estonia from Russia. Because of the lack of molecular genetic data, it is unclear whether it was the western I. cembrae or the eastern I. subelongatus that was recorded in St. Petersburg and in Kola Peninsula.

Besides qualitative changes in the species lists for the northern and southern parts of the region, there are also differences in the relative abundance of many species in different provinces. For example, Hylurgops glabratus Zett. has significantly substituted for I. typographus L. in Northern Karelia (Paanajärvi). H. glabratus has become a much more common species already in the northern and especially in the eastern parts of the Leningrad Province compared with its southern parts.

However, with the present study our aim was to compare only the species lists of different regions. The comparison allowed us to redefine the contemporary distribution range of nine European bark beetle species: Scolytus scolytus, $S$. 
multistriatus, S. laevis, Hylastes ater, H. opacus, Orthotomicus longicollis, Pityogenes trepanatus, Ips amitinus and Cryphalus abietis.

Acknowledgements. M. M. is grateful to A. K. Chistyakova, B. M. Kataev, B. A. Korotyaev (Zoological Institute, St. Petersburg), N. B. Nikitsky (Zoological Museum, Moscow), A. S. Leley and G. S. Lafer (Institute of Biology and Soil Sciences, Vladivostok) for help in work with collections, to R. Danielsson (Zoological Museum, Lund, Sweden) and to H. Schönmann (Natural History Museum, Vienna, Austria) for providing museum specimens for the study, and to A. S. Karpov and M. A. Marinich for their kind permission to join the Valamo expedition of the St. Petersburg State University. The authors also thank two anonymous referees for the valuable remarks on the earlier draft of the manuscript, Ester Jaigma and Aita Meier for the revision of English and Mait Lang for technical assistance. The work of the Estonian team was partly supported by grant No. 4728 from the Estonian Science Foundation.

\section{References}

Bright, D.E., Skidmore, R.E. 2002: A catalog of Scolytidae and Platypodidae (Coleoptera), Supplement 2 (19951999). - NRC Research Press, Ottawa.

Browne, F.G. 1972: Some oriental Scolytidae and Platypodidae (Coleoptera). — Oriental Insects 6(1): 19-32.

Gärdenfors, U. (ed.) 2000: Rödlistade arter i Sverige 2000. The 2000 Red List of Swedish Species. ArtDatabanken, SLU, Uppsala.

Gornostaev, P. 1917: Contributions a la faune des Scolytiens du gouvernement de Petrograd (Coleoptera, Ipidae). - Revue Russe d'Entomologie 16(3-4): 308-315. [In Russian].

Hämet-Ahti, L., Palmén, A., Alanko, P., Tigerstedt, P. M. A. \& Koistinen, M. 1992: Suomen puu- ja pensaskasvio. (Woody flora of Finland). $2^{\text {nd }}$ ed. Dendrologian Seura, Helsinki.

Heliövaara, K., Peltonen, M., Mannerkoski, I. \& Siitonen, J. 1998: Suomen kaarnakuoriaiset (Coleoptera: Scolytidae). - Helsingin Yliopisto, Soveltavan Eläintieteen Laitos, Julkaisuja 25: 1-91.

Heliövaara, K., Väisänen, R. \& Immonen, A. 1991: Quantitative biogeography of bark beetles (Coleoptera, Scolytidae) in northern Europe. - Acta Forestalia Fennica 219: 1-35.

Konca, B. 1995: Zmiany w wystepowaniu wybranych gatunkow owadow na Dolnym Slasku. (Changes in the distribution of some insect species in Lower Silesia.) - Sylwan 139(7): 69-73. [In Polish with English summary].

Koponen, M. 1975: Distribution of Ips amitinus Eichh. (Coleoptera, Scolytidae) in Finland in 1950-1973. Ann. Ent. Fenn. 41: 65-69.

Koponen, M. 1980: Distribution of Ips amitinus Eichh.
(Coleoptera, Scolytidae) in Finland in 1974-1979. Not. Entomol. 60: 223 - 225.

Kotiranta, H., Uotila, P., Sulkava, S. \& Peltonen, S.-L. (eds.) 1998: Red Data Book of East Fennoscandia. Ministry of the Environment, Finnish Environment Institute and Botanical Museum \& Finnish Museum of Natural History, Helsinki. 351 pp.

Kristian, J. 1937: Mõnest uuest üraskiliigist Eestis. (Some new bark beetle species in Estonia). — Eesti Mets 12: 399. [In Estonian].

Kurenzov, A. I. 1941: Bark beetles of the Far East, USSR. — Editions de l'Academie des Sciences de l'URSS, Moscou-Leningrad. 234 pp. [In Russian, with description of new species in English].

Leius, K. 1939: Täiendavaid andmeid kodumaa ürasklaste (Ipidae) fauna kohta. (Ergänzende Angaben über die Borkenkäfer-Fauna (Ipidae) in Estland. - Eesti Metsanduse Aastaraamat 9: 317-328. [In Estonian with German summary].

Lekander, B., Bejer-Petersen, B., Kangas, E. \& Bakke, A. 1977: The distribution of bark beetles in the Nordic countries. - Acta Entomologica Fennica 32: 1-37+ 78 maps.

Löyttyniemi, K. 1975: On the occurrence of Ips sexdentatus (Börner) (Col., Scolytidae) in South Finland. — Annales Entomologici Fennici 41(4): 134-135.

Lundberg, S. 1995: Catalogus Coleopterorum Sueciae. Naturhistoriska Riksmuseet, Entomologiska Föreningen, Stockholm.

Mandelshtam, M. Ju. 1999: Current status of Ips amitinus Eichh. (Coleoptera, Scolytidae) in North-West Russia. — Entomol. Fennica 10: 29-34.

Mandelshtam, M. Yu. \& Popovichev, B. G. 2000: Annotated list of bark beetles (Coleoptera, Scolytidae) of Leningrad province. - Entomological Review 80: 887-903 (Translated from Ent. Obozr. 79(3): 599618).

Mandelshtam, M. Ju. \& Selikhovkin, A. V. 2003: (Annotated list of bark beetles (Coleoptera: Scolytidae) of the National Park "Sebezhski".) — Priroda Pskovskogo kraya. Nature of Pskov Lands 15: 14-19. [In Russian].

Martikainen, P. 2000: Flight period and ecology of Trypodendron proximum (Niijima) (Col., Scolytidae) in Finland. - J. Appl. Ent. 124: 57-62.

Martikainen, P. 2001: Non-target beetles (Coleoptera) in Trypodendron pheromone traps in Finland. - Anz. Schädlingskunde /J. Pest Science 74: 150-154.

Martikainen, P., Siitonen, J., Kaila, L. \& Punttila, P. 1996: Intensity of forest management and bark beetles in non-epidemic conditions: a comparison between Finnish and Russian Karelia. - J. Appl. Ent. 120: 257-264.

Martikainen, P., Siitonen, J., Kaila, L., Punttila, P. \& Rauh, J. 1999: Bark beetles (Coleoptera, Scolytidae) and associated beetle species in mature managed and oldgrowth boreal forests in southern Finland. - For. Ecol. Manage. 116: 233-245.

Mattila, A. \& Vakkari, P. 1997: Genetic variation of Quercus robur and Ulmus laevis in Finland. - 
Metsanduslikud Uurimused 28: 63-68.

Mikutowicz, J. M. 1905: Zur Koleopterenfauna der Ostseeprovinzen Russlands. - Korrespondenzblatt des Naturforscher-Vereins zu Riga 48: 73-92.

Moe, D. 1970: The post-glacial immigration of Picea abies into Fennosandia. - Bot. Notiser 133: 61-66.

Mosolevskaja, E. G., Galasjeva, T. V. \& Chemeris, M. V. 1991: (The species and xylophagous insects spatial distribution pecularities in "Kivach" Nature Reserve.) - In: Yakovlev, E. B. \& Mosolevskaja E. G. (eds.), Entomologicheskie issledovaniya $\mathrm{V}$ zapovednike "Kivach" (Entomological researches in "Kivach" Nature Reserve): 66-74. Karelian Centre of the USSR Academy of Sciences, Petrozavodsk. 155 pp. [In Russian].

Mozolevskaya, E. G. \& Sharapa, T. V. 1996: Species composition of the xylophagous insects of the Murmansk province. - Ent. Obozr. 75(3): 558-566. [In Russian].

Mozolevskaya, E. G., Yakushkin, E. A. \& Lipatkin, V. A. 1981: (Species composition and ecological complexes of xylophagous insects in the forests of Murmansk province.) - Doklady MOIP, Zoology and Botany 1979. Nauka, Moscow: 93-95. [In Russian].

Muona, J. 1990: Four species of Coleoptera new to Finland. - Notulae Ent. 69: 195-197.

Muona, J. 1994: Tarkennuksia eräiden kuoriaislajien esiintymiseen Suomessa ja Venäjän Karjalassa (Coleoptera). (New distributional data on some Coleoptera in Finland and Russian Karelia). - Sahlbergia 1: 7-10.

Muona, J. \& Viramo, J. 1986: The Coleoptera of the Koillismaa area (Ks), North-East Finland. — Oulanka Reports 6: 3-50.

Nestertschuk, G. I. 1930: Die Wälder des KarelienMurman-Gebiets und ihre Schädlinge. — Morbi Plantarum (Bolesni Rastenij) 19: 159-181 [In Russian with German summary].

Nikitsky, N. B., Osipov, I. N., Chemeris, M. V., Semenov, V. B. \& Gusakov, A. A. 1996: The beetles of the Prioksko-Terrasny Biosphere Reserve - xylobiontes, mycetobiontes, and Scarabaeidae (with the review of the Moscow region fauna of the groups). - Archives of Zoological Museum Moscow State University 36: 1-197. [In Russian with English abstract].

Nikitsky, N. B., Semenov, V. B. \& Dolgin, M. M. 1998: The beetles of the Prioksko-Terrasny Biosphere Reserve - xylobiontes, mycetobiontes, and Scarabaeidae (with the review of the Moscow region fauna of these groups). - Archives of Zoological Museum Moscow State University 36, Suppl. 1: 1-60. [In Russian with English summary].

Nuorteva, M. 1955: Fennoskandialle uusi kaarnakuoriaislaji Ips amitinus Eichh. tavattu Suomesta. (Ips amitinus Eichh. (Col., Scolytidae) neu für Fennoscandien). - Ann. Ent. Fenn. 21: 30-32.

Nuorteva, M. 1963: Die Borkenkäfer (Col., Scolytidae) von Virolahti, Südostfinnland, und deren natürliche Insektenfeinde. - Ann. Ent. Fenn. 29: 281-282.

Nuorteva, M. 1971: Die Borkenkäfer (Col., Scolytidae) und deren Insektenfeinde in Kirchspiel Kuusamo, Nordfinnland. - Ann. Ent. Fenn. 37: 65-72.
Õunap, H. 1996: On Hylesinus Fabricius and Crypturgus Erichson (Coleoptera, Scolytidae) in Estonia. Metsanduslikud Uurimused 27: 133-139. [In Estonian with English summary].

Petrov, A. V. \& Nikitskii, N. B. 2001. Scolytid fauna (Coleoptera, Scolytidae) of Moscow province. — Ent. Obozr. 80: 353-367. [In Russian].

Pfeffer, A. 1994: Zentral- und westpaläarktische Borkenund Kernkäfer (Coleoptera: Scolytidae, Platypodidae). — Entomologica Basiliensia 17: 1-310.

Platonoff, S. 1943: Zur Kenntnis der Käferfauna um den See Paanajärviin Kuusamo, Nordfinnland. - Not. Entomol. 23: 76-144.

Postner, M. 1974: Scolytidae (= Ipidae), Borkenkäfer. In: Schwenke, W. (ed.), Die Forstschädlinge Europas, Bd. 2, Käfer: 334-482. Verlag Paul Parey, Hamburg, Berlin. 500 pp.

Rener, I., Maja, J. 2001: The six-toothed bark beetle Ips sexdentatus (Boerner, 1767) (Coleoptera: Scolytidae) in the fire site Kojnik. - Journal of Forest Science 47 (Special Issue 2): 154-155.

Rubel, S. 1964: Eesti ürasklaste (Ipidae) määraja. (Key to the Estonian bark beetles). — Eesti Põllumajanduse Akadeemia, Tartu, 56 pp. [In Estonian].

Rutanen, I. \& Kashevarov, B. 1997: Coleoptera of the Nature Reserve Friendship with adjacent primeval forests. In: Lindholm, T., Heikkilä, R. \& Heikkilä, M. (eds.), Ecosystems, fauna and flora of the Finnish-Russian Nature Reserve Friendship: 257-294. The Finnish Environment, Finnish Environment Institute, Helsinki.

Saalas, U. 1917: Die Fichtenkäfer Finnlands. — Ann. Acad. Sci. Fenn. Ser. A, VIII, 1: 1-547.

Saalas, U. 1923: Die Fichtenkäfer Finnlands. — Ann. Acad. Sci. Fenn. Ser. A, XXII, 1: 1-576.

Saalas, U. 1931: Über die Verbreitung der Borkenkäfer (Ipidae) in Finnland. - Verh. Deutschen Ges. angew. Ent., 8. Mitgliederversammlung in Rostock: 65-71.

Schönherr, J., Vite, J. P. \& Serez, M. 1983: Überwachung von Ips sexdentatus-Populationen mit synthetischem Lockstoff. — Zeitschrift für angewandte Entomologie 95(1): 51-53.

Sharapa, T. V. 1985: The bark-beetles of Kandalaksha Nature Reserve spruce forests. - Nauchnye Trudy MLTI, Moscow, Issue 167: 172-174. [In Russian].

Sharapa, T. V. \& Shcherbakov, A. N. 2000: The dynamics of Nature Reserve "Kivach" forest stands. Ecology, monitoring and rational use. - Nauchnye Trudy MGUL, Moscow, Issue 302(1): 38-45. [In Russian].

Siitonen, J. 1990: Potential forest pest beetles conveyed to Finland on timber from the Soviet Union. - Silva Fennica 24(3): 315-321.

Siitonen, J. 2000: Beetles (Coleoptera) imported to Finland on Russian roundwood. - Aktuelt fra Skogforskningen 4: 11-17.

Siitonen, J. \& Martikainen, P. 1994: Occurrence of rare and threatened insects living on decaying Populus tremula: a comparison between Finnish and Russian Karelia. Scand. J. For. Res. 9: 185-191.

Siitonen, J., Martikainen, P., Kaila, L., Nikula, A., Punttila, P. 1995. Kovakuoriaislajiston monimuotoisuus eri tavoin 
käsitellyillä metsäalueilla Suomessa ja Karjalan tasavallassa. - Metsäntutkimuslaitoksen Tiedonantoja 564: 43-63.

Siitonen, J., Martikainen, P., Kaila, L., Mannerkoski, I., Rassi, P. \& Rutanen, I. 1996: New faunistic records of threatened saproxylic Coleoptera, Diptera, Heteroptera, Homoptera and Lepidoptera from the Republic of Karelia, Russia. - Entomol. Fennica 7: 69-76.

Silfverberg, H. 1992: Enumeratio Coleopterorum Fennoscandiae, Daniae et Baltiae. - Helsingin Hyönteisvaihtoyhdistus, Helsinki. 94 pp.

Sippola, A.-L., Siitonen, J. \& Kallio, R. 1995: Faunistics of Coleoptera in subarctic pine forests in Finnish Lapland. — Entomol. Fennica 6: 201-210.

Stark, V. N. 1930: (Bark beetles of the forests at Chibiny, Lapland). - Zaschita Rastenij 7: 19-28. [In Russian].

Stark, V. N. 1952: (Fauna of the USSR. Coleoptera. Vol. 31. Bark-beetles). - Izdatelstvo Akademii Nauk SSSR, Moscow-Leningrad. 462 pp. [In Russian].

Stauffer, C., Kirisits, T., Nussbaumer, C., Pavlin, R. \& Wingfield, M. J. 2001: Phylogenetic relationships between the European and Asian eight spined larch bark beetle populations (Coleoptera, Scolytidae) inferred from DNA sequences and fungal associates. - European Journal of Entomology 98: 99-105.

Süda, I. 2001: Ksülobiontsete mardikaliste (Coleoptera) väljakasvatamise tulemused aastail 1994-2000. (The results of the rearing of xylobiont beetles (Coleoptera) in 1994-2000). — Metsanduslikud Uurimused 35: 179188. [In Estonian with English abstract].

Telnov, D., Barsevskis, A., Savich, F., Kovalevsky, F., Berdnikov, S., Doronin, M., Cibulskis, R. \& Ratniece, D. 1997: Check-list of Latvian beetles (Insecta: Coleoptera). - Mitteilungen des Internationalen Entomologischen Vereins e. V. Frankfurt a. M. Suppl. V, 141 pp.

Titova, E. V. 1959: (Bark beetles of conifer undergrowth on forest clearcuttings of Karelia). — Trudy Karelskogo filiala AN SSSR 16: 110-126. [In Russian].

Viramo, J. 1996: A checklist of Insecta (excl. Diptera, Siphonaptera and Hymenoptera) of the biological province Koillismaa (Ks; Regio Kuusamoensis). - Oulangan Biologisen Aseman Julkaisuja 4. Oulun Yliopisto, Oulu. 75 pp. [In Finnish].

Voolma, K. 1996: Distribution of xylomycetophagous scolytids (Trypodendron and Xyleborus) in Estonia. Metsanduslikud Uurimused 27: 140-148. [In Estonian with English summary].

Voolma, K., Õunap, H. \& Süda, I. 1996: Ürasklased (Coleoptera, Scolytidae) Eesti entomoloogilistes kollektsi- oonides. (Bark beetles (Coleoptera, Scolytidae) in the insect collections of Estonia). - Metsanduslikud Uurimused 27: 125-132. [In Estonian with English summary].

Voolma, K., Õnap, H. \& Süda, I. 1997a: Bark beetles (Coleoptera, Scolytidae) of Estonia: results of the examination of insect collections. - Baltic Forestry 3: 19-23.

Voolma, K., Õunap, H. \& Süda, I. 1997b: Eesti ürasklaste määraja (Coleoptera, Scolytidae). (Key to the bark beetles (Coleoptera, Scolytidae) of Estonia). — Eesti Põllumajandusülikool, Metsandusteaduskond, Tartu. 43 pp. [In Estonian ].

Voolma, K., Õunap, H. \& Süda, I. 2000: Ürasklased Scolytidae. - Distribution Maps of Estonian Insects 2. Tartu. 84 pp.

Voolma, K. \& Süda, I. 1999: Rare species of Cerambycidae and Scolytidae (Coleoptera) in Estonia. — Proceedings of the XXIV Nordic Congress of Entomology, Tartu: 187-192.

Voolma, K., Süda, I. \& Õunap, H. 1998: New records of bark beetles (Coleoptera, Scolytidae) from Estonia. - Proc. Estonian Acad. Sci. Biol., Ecol. 47(1): 73-78.

Yakovlev, E. B. 1996: On the characteristics of communities of saproxylic Coleoptera in unmanaged forests of Russian Karelia. - In: Krutov, V. I. et al. (eds.), Problemy antropogennoi transformatsii lesnykh biogeotsenosov Karelii: 139-166. Karelskij nauchnyi centr RAN, Petrozavodsk. [In Russian].

Yakovlev, E. B., Scherbakov, A., Polevoi, A. \& Humala, A. 2000: Insect fauna of the Paanajärvi National park and proposed Kalevala National park with particular emphasis on saproxylic Coleoptera, Diptera and Hymenoptera. —-In: Heikkilä, R., Heikkilä, H., Polevoi A. \& Yakovlev, E. (eds.), Biodiversity of old-growth forests and its conservation in north-western Russia: 103-157. Regional Environmental Publications 158. North Ostrobothnia Regional Environment Center, Oulu.

Yakovlev, E. B., Shorochov, V. V. \& Gorbunova, V. N. 1986: Materials to knowledge of fauna of the Karelian xylophagous beetles. - In: Yakovlev, E. B. \& Uzenbajev, S. D. (eds.), Fauna i ecologiya chlenistonogih Karelii: 40 59. Karelskij filial AN SSSR, Institut Lesa, Petrozavodsk. [In Russian].

Zolk, K. 1932: Kodumaa ürasklased (Ipidae) ühes lühikese ülevaatega nende bionoomiast ja levimisest Eestis. Die Borkenkäfer (Ipidae) Estlands mit kurzer Berücksichtigung ihrer Bionomie und Verbreitung. — Eesti Metsanduse Aastaraamat 6: 127-176. [In Estonian with German summary]. 